\title{
Baldomero Sanín Cano, Sabiduría Libertadora
}

Pocos americanos merecen y reclaman el homenaje cívico como don Baldomero Sanín Cano, gran patriarca de nuestras letras. La idea feliz de rendirle pleitesía, puesta en marcha por la limpia vigilancia de Manuel Pedro González, tiene el respaldo fervoroso de todos los escritores honestos del continente.

$\mathrm{Su}$ afortunado iniciador ha advertido que este homenaje a Sanín Cano está más allá de toda ubicación política, por encima de toda definición ideológica. No está mal la advertencia. Pero digamos que si el homenaje se produce es en realidad por el cumplimiento, en quien lo recibe, de una grande y ejemplar política intelectual que todos consagramos ahora con nuestra devoción.

Don Baldomero Sanín Cano es el mejor representativo de una política intelectual que viene de Heredia, de Bello, de Olmedo, de Sarmiento, de Lastarria, de Alberdi, de Cecilio Acosta, de Hostos, de Martí y de Varona. Consiste esa política, entrañablemente americana, en hacer de la literatura una comunicación magnánima, un modo austero y generoso de servicio colectivo. No todos estos varones ejemplares fueron de igual raíz y resonancia. En todos había ciencia y sed, seso y pasión. Pero los hubo inspirados y los hubo noticiadores, primordialmente. Unos y otros dieron a nuestros pueblos lo indispensable: sustancia para luchar y fuego para vencer. A veces, como en Simón Bolívar, José Martí, José Carlos Mariátegui y Aníbal Ponce, la palabra fué bandera, sin olvido de ser entendimiento, gracia y hallazgo.

Sanín Cano será siempre para mí, para mí que lo quiero hace muchos años como a un claro padre lejano, el escritor civilizador, ac- 
tualizador, esclarecedor, iluminador. Por eso es un gran político letrado. Porque hay casos excesivos - los nombres me brincan entre las teclas de la Underwood-, en que el trato gustoso del pasado esclaviza para siempre al escritor. Lo viejo se hace ambiente $y$, por lo tanto, atmósfera, ámbito para el pulmón envejecido, tibia servidumbre, cadena perpetua. Como a esos covachuelistas hechos a la oscuridad de la zahurda, lo que ocurre en la calle les perturba y malhumora. $Y$ cuando los ruidos vitales les fuerzan a mirar hacia afuera, todo lo ven confuso y deforme, listado de la negrura habitual, ya inseparable de sus ojos. Hay por toda nuestra América como una familia letrada sumergida que se hace señales consabidas, definitivamente ciega ante las esencias dinámicas que nos llevan a las grandes realizaciones.

Sanín Cano es, en el mejor entendimiento del vocablo, un escritor sabio, pero de una sabiduría de piernas animosas que no se da mucho por nuestras tierras obstinadas. Cuantas veces lo leo y medito, me sorprende esa ancha estimación de los hechos humanos, que si llega al fondo de lo antiguo, descubre proyecciones de lo que está andando hacia el mañana. Es que don Baldomero tiene, como Miguel de Cervantes y Antonio Machado, esa libertadora condición de la ternura, esa llave abridora de todos los misterios que es la fe en el hombre y en su destino.

Nuestra América ha de ser cada día más ella, pero sin dar la espalda a un entronque cultural que le viene de lo mejor de Europa, en lo que tiene Europa de levadura activa y libertadora. Sanín Cano ha sido, ante todo y antes que todos, el magno comunicador de esas potencias, el gran definidor, sin más pasión que la de la verdad. A veces nuestros escritores olvidan que lo que repiten sobre la peripecia política y cultural de Europa y de los Estados Unidos, nos lo trasmitió impecablemente el maestro de Colombia, nos lo entregó don Baldomero limpio del polvo misoneísta y de la paja del escándalo efímero.

En América, muy en razón de nuestro tumultuoso aislamiento y de nuestra necesidad de información leal, no se cumple la función intelectual sino con signo periodístico. $\mathrm{Y}$ no estamos aludiendo a lo periodístico formal, a escribir artículos todos los días, autnque por ahí puede y debe andar lo eficaz; nos referimos a un modo de trabajo intelectual que puede tomar las vías del ensayo y de la no- 
vela, de la polémica y de la conferencia, y en que debe ser permanente el intento de enterar, de distinguir, de enjuiciar, de servir. Tales funciones las ha cumplido como nadie Baldomero Sanín Cano y su caso es muy válido para probar que la tarea esencial del periodismo - periodicidad esforzada y generosa-, en nada merma ni estorba ni rebaja la calidad intrínseca de la obra. Todos agradecemos a Sanín Cano su dilatada tarea explicándonos hombres, hechos y fenómenos; por ello lo honramos; pero tal honra no se produciría si el servicio informador no hubiera trasmitido siempre una calidad de escritor sostenida, depurada, singular y distinta.

Otros le aclamarán la ancianidad ilustre a este trabajador sin cansancios aludiendo a sus virtudes numerosas de escritor, a su varia y gentil cultura, a su cernida erudición, a su rara capacidad de ordenación y síntesis. Todo ello pide "pleitesía. Yo se la rindo. Pero, hombre político que soy, he de tener en más el trabajo primordial que nuestros pueblos le deben a Sanín Cano; el servicio de cultura en el sentido real y fecundo; la tarea de decir a nuestras gentes ávidas durante medio siglo cómo son los movimientos sociales, las conmociones espirituales, los cambios de estilo, el sentido de una guerra, de una revolución o de una doctrina.

Para las grandes transformaciones que va a encarar nuestro continente, es suerte y privilegio muy trascendentes tener vivos y viviendo a hombres como don Baldomero Sanín Cano. Hasta ahora limpiaron los caminos, desbrozaron la manigua estorbosa, disolvieron fantasmas y denunciaron secuestradores embozados en los montes. Mañana será la hora de sumar el alto servicio al ímpetu activo de justicia que rompe ya por campos y ciudades de América.

Juan Marinello 
